\title{
Flipping Learning to Develop Students' Engagement and Achievement in the Computer Applications Unit as Part of Their Studies on the Sub- ject of Instructional Design
}

\author{
Abdullah K. Alodail ${ }^{*}$ \\ Albaha University, Saudi Arabia \\ Received: 20/11/2019 \\ Accepted: $16 / 4 / 2020$
}

\begin{abstract}
The study aimed to measure the impact of using the flipped learning strategy on students' engagement and achievement when creating computer applications. The study used a quasi-experimental approach to prepare the literature framework and two measurement tools, including an achievement test and an engagement scale. The study sample consisted of 42 learners. The researcher used a t-test to measure the differences between the control group (taught by a traditional method) and experimental group (taught using the flipped learning strategy). The content of the pre-class consisted of videos, PowerPoint presentations and the use of appropriate URLs, which was provided through an Easy class platform. Students worked individually and cooperatively during the class activities. The results showed that there were statistically significant differences at $a \leq 0.05$ between the means of the experimental and control groups in the post-tests on both achievement and learning engagement. This was in favor of the experimental group, which used videos, presentations and web links on the subject of achievement and learning engagement, unlike the control group that used a traditional method.
\end{abstract}

Keywords: Flipped classroom, easyclass, computer application, learning engagement.

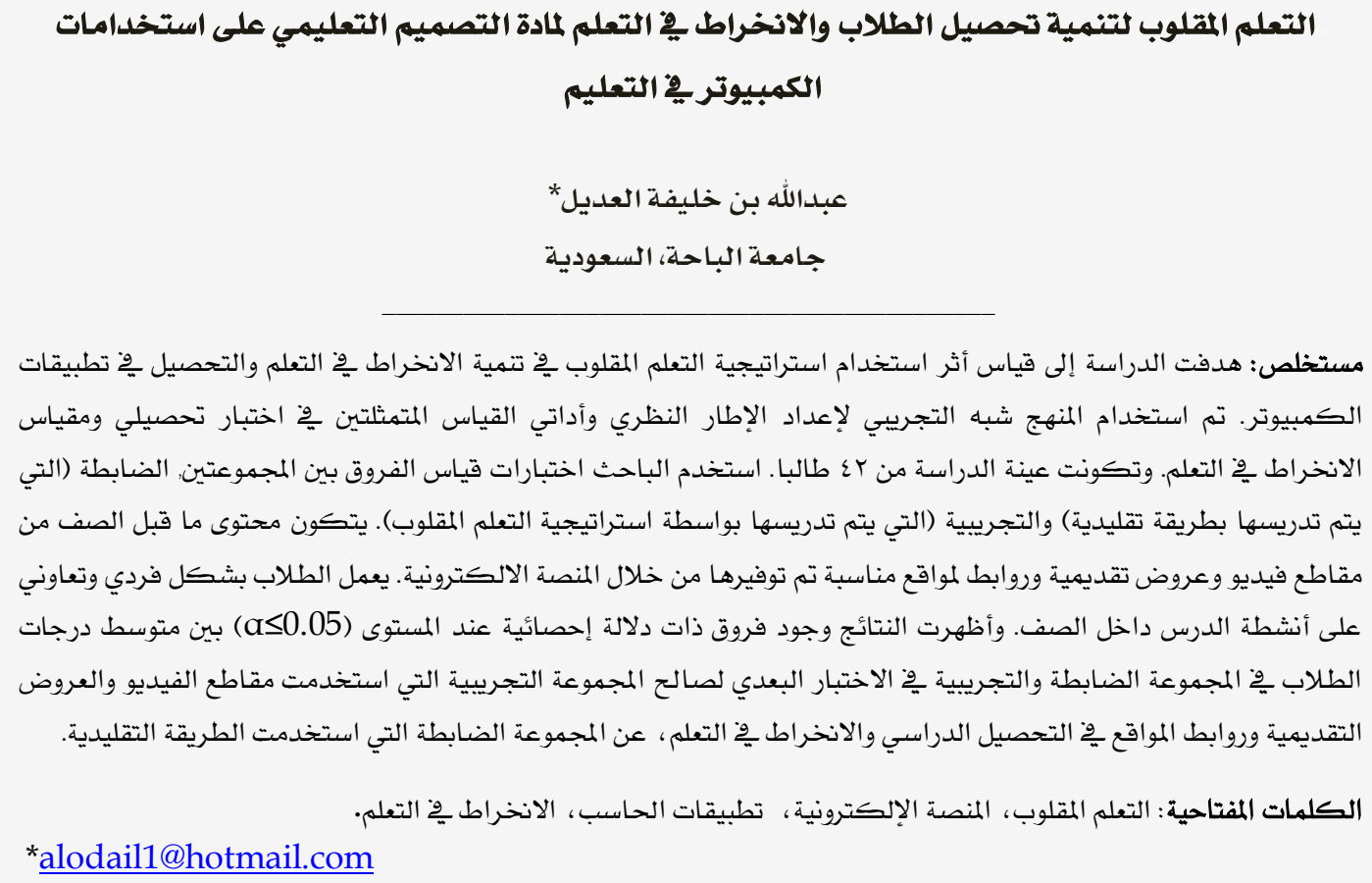


Teaching is a process that requires teachers to plan and make decisions about classroom practices, and teachers often rely on their beliefs and professional knowledge to guide them (Berthelsen, Brownlee \& Lewis, 2002).

According to Sahin and Turan (2009), whose study aimed to establish the impact of using technology on learning and teaching in a classroom environment, only pedagogically sound teaching and appropriate technologies lead to improvements in learning. In addition, their study found that, from the point of view of the students who participated, the integration of technology in learning requires some critical skills.

The rapid growth of technology has revolutionized the world of education, playing an important role in both learning and teaching today. However, the use of technology without applying appropriate pedagogy will not have much impact. The flipped classroom is a form of teaching that has emerged from the spread of technology. It consists of mixed-learning models that focus on student-centered learning activities, thus providing students with a self-paced learning environment. Consequently, students can learn according to their learning abilities using technology as an intermediary. In addition, when using this method, classroom instruction also emphasizes active learning activities, resulting in greater opportunities for interaction and collaboration. The flipped classroom has been demonstrated through the experimental use of technology to improve students' achievement and learning engagement. However, the use of technology does not replace the role of the teachers. This paper will discuss the use of technology in the flipped classroom based on previous studies and present the challenges involved in the implementation of flipped classroom methods. This paper will also make a comparative study of the use of technology in the flipped classroom to reveal the which technology applications have the most potential to benefit students' engagement and achievement when implemented.

Lage, Platt and Treglia (2000) defined flipped learning as the opposite of tradi- tional classroom methods that are commonly used in and out the classroom. The flipped learning strategy is generally categorized as mixed or coeducational learning, as it uses active problem-based learning methods and modern techniques to engage students (Arnold-Gaza, 2014). Moreover, Bishop (2013) defined flipped learning as a strategy that involves a combination of learning theory, such as constructivist theory, through the use of problem-based learning and behaviorism theory via the use of lectures on the Internet. A study by Zhou and Jiang (2014) described flipped learning as a generalized technique that consists of interactive activities in the classroom and educational assignments outside the classroom.

Flipped learning can play a critical role in assisting teachers to increase students' engagement and achievements in Saudi Arabia. As stated by Bergman and Sams (2012), flipped learning results in the student being the focus of the educational process, provides opportunities for selflearning, ensures high levels of learning, gives the student immediate feedback, increases discussion time between students and the teacher, provides the opportunity for evaluation and treatment, and allows learners to participate more in learning.

As a consequence, flipped learning has become a crucial platform in the educational environment. Therefore, the current study seeks to explore the interaction between preparation and treatment to reach the appropriate educational design through three elements of multimedia. Furthermore, the current study explores the impact of flipped learning strategy on students studying the subject of computer application on learners' engagement and achievement during class activities.

The results of Karagöl and Esen's recent study (2019) revealed that the flipped learning method has a positive impact on academic achievement in comparison with traditional learning approaches. Furthermore, they found that the effect of flipped learning on academic achievement is higher in small groups, and there is a significant difference between groups, depending on whether they are from one 
nation or comprised of international students.

Jdaitawi (2019) conducted a study aimed at exploring the impact of a flipped classroom strategy on student's self-regulation and social connectedness during preparatory year education. They used a quasiexperimental pre-post-test design, and the study sample included 160 university students at Imam Abdulrahman Bin Faisal University, Saudi Arabia. The students were divided into two groups: an experimental flipped classroom group taught using flipped learning, and a control group taught using a traditional approach. The study tools consisted of selfregulation and social connectedness questionnaires. The results of the study demonstrated that there was a significantly high-level of self-regulation and social connectedness for students in the flipped learning group compared to students in the group taught with a traditional technique. The results show that a flipped classroom strategy can be used to promote self-organized learning to enhance students' social connectedness.

In addition, a study by Huang, Liaw and Rauch (2010) showed that structural theory supports the concept of active learning experiences, which directly links the learner to knowledge in order to create new knowledge, and thus improve their thinking and problem-solving abilities.

\section{Study Problem}

Several studies have highlighted the challenges faced by university students in higher education institutions. These include limited self-regulated learning approaches, low levels of connectedness, a lack of motivation, a lack of leisure time, and poor achievement in academia (Zorofi, Gargari, Geshlagi, \& Tahvildar, 2011; Ozben, 2013; Geduld, 2016; Turki, Jdaitawi, Sheta, 2018). Therefore, to discover the impact of this method on their engagement and academic achievement, the flipped classroom strategy was used in the study, with the expectation it would improve learning outcomes.

Davies, Dean and Ball (2013) stated that the process of shifting from a traditional classroom to a flipped classroom can be difficult, due to a lack of facilities, effective model and poor Internet access. However, lecturers can enrich presentations by integrating multimedia content as an innovative approach to teaching, for example by using PowerPoint (Leicht, Zappe, Messner, \& Litzinger, 2012). However, students still have to memorize the material included in the notes and PowerPoint slides, which in itself does not increase classroom engagement (Ahlfeldt, Mehta, \& Sellnow, 2005).

It is important to understand what causes engagement, as it may not be due to environmental reasons, lack of understanding or satisfaction, access of local education services (Kettlewell, Southcott, Stevens, \& McCrone, 2012) the implementation of the flipped classroom will improve students' engagement, leading to positive educational outcomes and improving their performance, as a result of the learning environment (Reeve, 2013; Wilson, 2013).

According to Sankoff (2014), traditional lectures often lead to a waste of precious resources and fail to take advantage of teachers' experience, knowledge, and abilities by making them deliver the same information to different groups. However, the flipped learning strategy has many advantages for students and teachers according to the literature. For example, Fulton (2012) listed the advantages of flipped learning as being the following: learners' study at their own speed and smartness, making effective use of class time, teachers are encouraged to develop professionally, and it provides an opportunity for group discussion and peer instruction.

The researcher first conducted a pilot study with a group of 20 learners outside the sample of the main study to determine any problems with the study. The study began with an achievement and engagement learning pretest to measure the starting point for the sample. The researcher detected a low achievement and engagement level of around $30-50 \%$ among students' knowledge of computer applications in education. This was perceived to be because of the ineffectiveness of traditional teaching methods, which prompted 
the researcher to use the flipped learning method, with the aim of increasing their engagement and achievement.

Indeed, according to previous research, active learning approaches often lead to higher engagement and learning achievements of students when compared to traditional teacher-centered curricula such as lectures (Zappe, Leicht, Messner, \& Lee, 2009, p.3).

Therefore, the study aimed to overcome the fact that students have not developed their knowledge of the applications of computers in the classes on the subject of instructional design through traditional teaching methods. This is due to the ineffectiveness of using traditional methods, and so it is proposed that the use of modern technology, specifically the flipped learning strategy, will address this deficiency, as reflected by the findings of the studies featured in the literature review.

The researcher identified a low achievement and engagement level among students regarding their development of computer application in education, indicating that traditional methods of teaching are not very effective. Therefore, the researcher felt that by changing the teaching approach to a more modern one, it could help students achieve more. In this case, the researcher sought to establish the impact of flipped learning on the achievement and learning engagement of students studying the computer applications unit of the selected subject at the Faculty of Education at Al-Baha University. It was expected that the use of flipped learning would increase students' engagement during the course and also result in them acquiring greater knowledge of computer applications. Therefore, the problem of the study centered on the lack of students' understanding of computer applications and the low level of engagement in the classes on this subject when taught by traditional methods. Thus, it was proposed that a flipped classroom was needed to implement the course material.

The researcher has worked as a faculty member at the Faculty of Education at Albaha University teaching males and females since 2013. Based on the researcher's experience, students' engagement and achievement have not reached their full potential due to the inability of traditional methods to attract and maintain students' attention. They also fail to meet their needs and provide practical training. Consequently, students frequently complain about the textbooks, which provide no opportunities for the practical application of what they learn, and thus result in a low level of engagement and achievement among students. Therefore, a more modern, effective approach must be used to develop students' academic engagement and achievement in a way that is attractive and meets their needs. The researcher's solution is through the frequent use of flipped learning.

Hence, the research problem was found in the following statement: students lack knowledge related to computer applications and do not engage to a great extent in the field of instructional design, because of the ineffectiveness of traditional teaching methods. Therefore, the use of the flipped learning strategy to address this deficiency is required.

\section{Study objectives}

In summary, the researcher aims:

1. To measure the effectiveness of flipped learning on students' achievements and engagement.

2. To test the significance of collecting data between two study groups based on teaching approach

3. To design a flipped classroom strategy for the computer applications unit.

\section{Study questions}

1. What is the impact of the flipped learning strategy on achievement for students studying computer applications for students at the Faculty of Education at Al-Baha University?

2. What is the impact of the flipped learning strategy on learning engagement for students studying computer applications at the Faculty of Education at Al-Baha University? 
3. Is there a significant relationship at the level $a \leq 0.05$ between students' engagement and achievement in the subject of computer applications?

\section{Hypothesis}

1. There are no significant differences at the level of $a \leq 0.05$ between the mean scores of the experimental group taught using a flipped learning approach and the control group taught using traditional methods during the pre and post-tests as a result of implementing the program.

2. There are no significant differences at the level of $a \leq 0.05$ between the mean scores of the experimental group taught using a flipped learning method and the control group using a traditional method during the learning engagement pre and post-tests as a result of implementing the program.

\section{Study importance}

1. Help educators select the most appropriate teaching approach for their area.

2. starting point for further research that can be applied to different areas across a range of higher education institutes.

\section{Study limitations}

The study was conducted at the Faculty of Education at Al-Baha University in Saudi Arabia, and included 42 students who registered for the course titled "Instructional design" during the first semester of 20192020. The researcher selected the "Computer Applications in Education" unit to track learners' achievements and engagement, as this particular unit involves reading a great deal of text. The study focused on students being taught using a flipped learning approach, which involved preclass assignments and out-of-class work, in addition to well-planned and designed activities to attract learners during their classes.

\section{Definition of terms}

- The term impact is defined as the effect of the investigation as an independent element on the dependent factors, or an individual's need to obtain goals, feedback, and experience achievements (Jain and Singh, 2017). Operationally, in this study, effectiveness refers to the statistical effect on the dependent variable, that is to say, the students' progress in learning the information featured in the unit titled Computer Applications after using the independent variable (flipped learning) as a teaching method.

- Lage, Platt and Treglia (2000) defined flipped learning as the opposite of the classroom means that it has traditionally happened inside the classroom and outside. Operationally, in this study, flipped learning refers to provide to students attending lectures featuring video, web resources and with a presentation format, as well as other homework materials.

- Engagement represents the range of action students take to advance from not knowing, not understanding, not having skill, and not achieving to knowing, understanding, having skill, and achieving (Reeve, 2013, p.580).

- According to Reiser and Dempsey (2007), the ADDIE model, which stands for analysis, design, development, implement, and evaluation, is a general process, and can be used to design a lesson. Operationally, it is an instructional design model to develop subjects and programs in several ways based on the five listed previously.

\section{Literature review}

Given our brain's ability to identify correlations, and patterns, studies show that visualizations and graphic representations improve user cognition (Hullman, 2011). 
The Internet is a platform where millions of people engage in the creation and exchange of information, and has had a significant effect on a student's academic achievement and social life. According to Emeka and Nyeche (2016), the Internet is defined as a large computer network connecting together millions of smaller computers belonging to thousands of businesses, governments, research centers, educational institutions and other organizations at numerous sites in nearly every nation. For Internet users, the Internet may be regarded as a worldwide community - one with a very active life. In today's world, the Internet plays a vital role in teaching, as well as the research and learning process in academic institutions.

The origin of the flipped learning strategy refers to Jonathan Bergmann \& Aaron Sams, two chemistry teachers from Colorado, who used recorded lectures to provide instruction to high school students who has missed their lessons (Bergman \& Sams, 2012). An Easy class platform was used as an online learning platform to deliver the best communication between teachers and students, and to allow them access anytime and anywhere, in order to improve students learning outcomes. Furthermore, Easy class was described as a useful tool for uploading course materials such as videos, teaching resources, group discussions, tasks, and quizzes about the lessons. Therefore, Easy class was used in this study as a means of creating a flipped classroom. Gross' (2014) study demonstrated that there were significant differences for students in a flipped learning classroom compared to students in taught using traditional methods. Their results showed that the flipped classroom strategy can be used to promote learning to enhance students' achievements.

The flipped classroom strategy can be categorized into three phases, namely preclass learning preparation, in-class learning activities and post-class learning consolidation (Kong, 2014, 2015). First, in the run-up to/as part of the pre-class learning, students view the material at their own pace using online learning platforms. This is followed by in-class learning activities, where the students conduct activities too? participatory learning activities by debating, discussing, presenting and simulating lesson content (Estes, Ingram, \& Liu, 2014; Tucker, 2012). In-class activities support and increase the students' understanding. Following these, post-class learning involves the reviewing of materials to improve learning outcomes, enabling students to learn outside the classrooms, practicing what they have learned, working together with peers, and getting teachers' feedback (Warter-Perez, \& Dong, 2012). Therefore, flipped learning has proved to have a significant impact on improving students' achievements when studying in different fields in higher education (Sergis, Sampson, \& Pelliccione, 2018).

However, previous studies that made comparisons of students' abilities and skills between traditional and flipped courses have reported mixed findings. To begin with, Wilson (2013) found that students' grades improved after flipped learning. However, no effect was found on students' achievement by Mc-Laughlin et al. (2013) after their students attended courses taught using flipped learning, although it was shown to increase their participation. At university level, students in a flipped classroom were shown to have cooperative scores compared to their peers in the control classroom. In the same study (Kwon \& Woo, 2018), the competitive mindset scores of the flipped classroom group showed a decrease compared to the control group. Similarly, Ok et al. (2017) revealed that flipped classroom students had overturned higher levels of perceived anxiety due to the use of an online learning environment, and the fact they participated in a blended course that had participants that had higher perceived satisfaction, perceived utility and self-regulation.

Saunders (2014) conducted a study aimed at exploring the impact of a flipped classroom strategy on high-school students' achievements and critical thinking in math. A quasi-experimental pre-post-test design was used in this study. The students were divided into two groups: an experimental group of 15 male students comprised the flipped classroom group, who were taught using flipped learning 
techniques, and a control group, which was made up of 15 female students taught using a traditional approach. The study tools consisted of critical thinking questionnaire. The results of the study demonstrated that there was no significant difference between the two groups in terms of achievement and critical thinking. The results recommended more studies being conducted to examine the impact of the flipped learning strategy on achievement and critical thinking.

A study by Elian and Hamaidi (2018) aimed to explore the impact of the flipped classroom strategy on students' achievements in the subject of science among fourth grade students in Jordan. The study sample consisted of 44 male and female students who were chosen purposely from the study population. A quasiexperimental pre-post-test design was used in this study. The sample were divided into two groups: the experimental group was comprised of 22 male students taught using the flipped learning method, and a control group consisting of $22 \mathrm{fe}-$ male students taught using a traditional approach. The study tools consisted of an achievement test. The results of the study demonstrated that there was a significant difference between the two groups in terms of achievements in favor of the experimental group, which was attributed to the teaching strategy and not attributed to gender. The results recommended encouraging science teachers to teach students using the flipped classroom strategy.

In this study, the research questions require the determination of whether significant differences exist in terms of engagement and achievement between the experimental and the control groups, due to the effect of flipped classroom strategy.

In a flipped learning environment, students become active learners who are involved in higher-level critical thinking, interactive and problem-solving activities and engage in deep learning using metacognition (Brame, 2013; Sharpe, 2016). For example, in a study by Tarazi (2016), students who were subjected to inverted teaching engaged in deep learning and showed a higher level of motivation. An- other feature of the flipped learning context is that students participate in the lower level cognitive work outside the classroom, and the higher level of cognitive work in the classroom (Sharpe, 2016), "where they have the support of the peers and instructors" (Brame, 2013, p. 1).

\section{Methodology}

\section{Research design}

The study belongs to the experimental design class (a quasi-experimental), as it was carried out on experimental and control groups, in order to see the influence of an independent variable on a dependent variable. In this study, the aim was to identify if there were any improvements in student engagement and achievement among those studying computer applications. This was measured by a learning engagement measure and an achievement test. In total, 42 learners from the Faculty of Education were included in the study, after being parity tested, during the first term of 2019. The main study lasted 4 weeks in duration. The strategy related to flipped learning use, including the achievement test, was devised by the researcher of this study and the measure tool was made by Dixson (2015).

This current study aimed to prove the theory that students' achievements and engagement can be improved through the use of flipped learning in the classroom. Therefore, a sample of learners from the Faculty of Education at Al-Baha University participated in classes that were taught using the flipped learning strategy. A quantitative data collection process was selected to provide a general picture of the research problem, and the $\mathrm{t}$-test method was used in this study to analyze the data. The goal of the descriptive design was focused on two aspects, specifically flipped learning usage, and learning engagement and achievements.

A quasi-experimental design approach, including pre and post-tests, was used in the current study. The two groups consisted of students that had not experienced the flipped learning strategy before and who had been taught by the researcher 
prior to the experiment, which occurred during the academic year 2018-2019.

\section{Participants}

The entire population for the Faculty of Education at Al-Baha University is 1,080 male college learners and 1,443 female college learners. Table 1 shows the design of the experimental and control groups, and the independent variable, which was the use of the flipped learning strategy. The dependent variables were students' engagement and achievement.

\section{Study procedure}

A pilot study was conducted prior to the main study, to ensure the reliability of the study instruments. The Easy class platform included video, web resources and presentations. In addition the engagement and achievement tests were used in the pilot study among a group of 20 participants outside the sample of the original study, in order to verify the suitability of the educational program and test the time (25minutes) allotted for the study sample, as well as to identify any obstacles that could interfere with the process of applying the program. The pilot experiment showed that there were no significant obstacles and that the time required for implementing the program in each lecture would be one hour. Following this, two groups were randomly chosen to participate in the study. The experimental group consisted of 22 students taught using flipped learning, and the control group was made up of 20 students, who were taught using traditional method. All of the participants were from the Faculty of Education and were exposed to 4 weeks of studying either in a flipped classroom or using a traditional approach. They were also all given a pre-test prior to the study and a post-test after completing the four weeks of the study. Students in the flipped classroom were introduced to the procedures and given student roles in every single session in order to save session time.

The study was conducted on male students. However, pre-experimental measures of study achievement and learning engagement were incorporated to ensure the equivalence of research groups for the study. The course topics were uploaded on Easy class three days prior to classes. The subject of computer applications was taught to students. In the first class after the pre-test, students were taught from a unit about computer applications in education, and during the classes students discussed and evaluated the lesson content, correcting each other when necessary. Students were given the chance to demonstrate/lead in the practical activity to prove they had mastered the knowledge and were engaged. The topics were also uploaded on Easy class for the students in the control group to look at, but no task was set for this group. Students in the control group were taught using the lecture method. At the end of the four weeks, the test was administered to the participants in both the experimental and control groups as a post-test to determine their engagement and level of achievement.

The topics covered as part of the computer applications in education unit included: patterns of computer use, methods of computer use, the advantages and disadvantages of computer use, designing lessons featuring computer use, educational software, and presentations. The researcher reviewed the literature related to the variables of the study, analyzed the content of the study unit, interviewed college instructors, and then showed the arbitrator the content.

In order to design the experimental manipulating materials, the researcher selected the ADDIE model. Figure 2 indicates the first stage of the instructional design (ADDIE model) of the study.

Table 1

The experimental design of the study

\begin{tabular}{|c|c|c|c|c|}
\hline Group & Pretest & Manipulating & Posttest & \multirow{3}{*}{$\begin{array}{l}\text { Discussion and } \\
\text { interpretation } \\
\text { of findings }\end{array}$} \\
\hline $\begin{array}{l}\text { Experimental } \\
\text { (22 learners) }\end{array}$ & $\begin{array}{l}\text { Achievement pretest } \\
\text { and engagement (O1) }\end{array}$ & $\begin{array}{l}\text { Teaching using the } \\
\text { flipped leaning strategy }(X 1)\end{array}$ & \multirow[t]{2}{*}{$\begin{array}{l}\text { Achievement posttest } \\
\text { and engagement }(\mathrm{O} 2)\end{array}$} & \\
\hline $\begin{array}{l}\text { Control } \\
\text { (20 learners) }\end{array}$ & & $\begin{array}{l}\text { Teaching using the traditional } \\
\text { method (X2) }\end{array}$ & & \\
\hline
\end{tabular}




\section{Analysis stage}

The literature and previous studies related to the flipped learning strategy and its impact was revised to prepare the theoretical framework of the study. The undergraduate students, who were the target audience of the study, were asked to read and prepare a lesson before the class, which included video, presentations and web resources. The study was conducted in the computer lab, as it allowed access to the Internet. The Computer Applications in Education unit was the focus content, because it contains applications and visuals that lend themselves to being taught via flipped learning. The experimental group studied the unit using a flipped learning strategy and the control group were taught using a traditional method.

\section{Design stage}

The flipped learning strategy included the use of three materials (video, links and presentation), which included 25 computer applications from the computer use that were studied by studying by flipped learning in the experimental group and a traditional method in the control group. This was done using computer codes with clear data, color and consistency of flipped learning. The scenario for the flipped learning strategy was drawn up. The achievement test was based on recall and cognitive goals, and featured 25 multiple choice questions to measure students' recall, comprehension and learning engagement using a scale of 19items and 5 choices. Then, a specification table was made based on the number of questions. Table 2 shows the reliability of the test.

\begin{tabular}{|c|c|c|c|c|}
\hline \multicolumn{5}{|c|}{$\begin{array}{c}\text { Table } 2 \\
\text { Test Reliability }\end{array}$} \\
\hline $\begin{array}{l}\text { Final } \\
\text { grade } \\
(\mathrm{n})\end{array}$ & $\begin{array}{l}\text { Average } \\
\text { of grades } \\
(\mathrm{m})\end{array}$ & $\begin{array}{l}\text { Standard } \\
\text { deviation } \\
\text { (a) }\end{array}$ & $\begin{array}{l}\text { Variation } \\
\text { of grades } \\
\text { (a2) }\end{array}$ & $\begin{array}{l}\text { Reliability } \\
\text { coefficient } \\
(\mathrm{r} 1,1)\end{array}$ \\
\hline 25 & 22.93 & 4.12 & 37.45 & 0.82 \\
\hline
\end{tabular}

The test results shown in Table 2 indicate that the reliability coefficient of the test is 0.82 , which in turn indicates that the test is of high stability, which is reassuring, as it was used as the test for the research sample. In addition, the stability coefficient obtained by the analysis of variance gives the minimum coefficient for the stability of the test. The minimum current stability factor is 0.82 , which means that the test is highly stable, reliable and can be used with a high degree of confidence.

The Spearman correlation coefficient was calculated based on the scores taken from the sample divided by the total score of the 5 comprehension level questions and the 20 recall questions. Table 3 shows the results of the correlation coefficients:

\begin{tabular}{|c|c|c|}
\hline \multicolumn{3}{|c|}{$\begin{array}{c}\text { Table } 3 \\
\text { Correlation coefficients between the degree } \\
\text { of each level and the total score of the } \\
\text { achievement test }\end{array}$} \\
\hline $\mathrm{N}$ & Level & Correlation coefficient \\
\hline 1 & Comprehension & 0.522 \\
\hline 2 & Recall & 0.610 \\
\hline
\end{tabular}

Table 3 indicates that the correlation coefficients between the score of each level and the total score of the test ranged between 0.522 and 0.610 , all of which are statistically significant at a level of significance of less than 0.01 . This finding indicates that the items of each test level are valid.

\section{The development stage}

The researcher used a flipped learning approach consisting of video, web links and presentations and designed the lesson content based on the unit, which was titled "Computer applications in education" and contained 25 computer applications taught during the pre-class assignments. The researcher started the production and testing of the methodology used in the project, then showed it to a number of reviewers in the technology department to check the clarity of the screen, availability, and the basics of building the blog. The researcher conducted a pilot study of 15 learners, who were not included as participants of the sample used in the main study, to establish any potential obstacles to the test, and the time needed to conduct the main study (time needed from the first student to the last student answering). The results of the pilot study indicated there were no obstacles hindering the application of the program. Also, it was concluded that an hour for each lecture was adequate. Then, the measurement tool was applied during the post hoc test, and the 
data was recorded and monitored. Following that, the data was processed statistically, and then the researcher analyzed and discussed the results, making recommendations and suggestions in light of the results.

To define the time required to take the test, 15 learners participated in a pilot study, and the test time needed was found to be 25 minutes. Cronbach's alpha value was 0.61 , which is indicative of a high validity. To understand the difficulty facing the researcher when applying the study, it is useful to examine the coefficients of ease and difficulty. In this case, the coefficients of ease ranged from 0.67 to 0.40 and that the difficulty coefficients for multiple choice of achievement test ranged from 0.34 to 0.51 . To clarify, the coefficient of ease and difficulty was almost/approximately $50 \%$. Figure 5 indicates the fourth stage of the instructional design (ADDIE model) of the study.

\section{Implementation stage}

The researcher tested the tools for the flipped learning strategy, then revised them in terms of their availability, mistakes, and sources by faculty peers, before adding links, videos and presentations to the Easy class platform. The information added for the experimental group included the title of the flipped learning approach, its goal, how to use it, and the study time. The researcher provided a contact email address and cellphone number for any inquiries related to the use. The age of the learners was between 20-24 years old, and 42 male learners participated, all with the ability to deal with visual and written comments. The unit on computer applications was the focus of study and a flipped learning approach was used to help to increase verbal, sensory, mental, and written study achievements, as well as the learners' engagement. Finally, the researcher began and ran the course.

Table 4

Reliability coefficient of content

\begin{tabular}{ccc}
\multicolumn{3}{c}{ Reliability coefficient of content } \\
\hline $\begin{array}{c}\text { Content Analysis } \\
\text { of concepts }\end{array}$ & $\begin{array}{c}\text { Number of } \\
\text { items }\end{array}$ & $\begin{array}{c}\text { Points of } \\
\text { difference }\end{array}$ \\
25 & 25 & $91 \%$ \\
\hline
\end{tabular}

The researcher analyzed the content of the computer applications unit (comprehension and recall goals). Table 4 shows the values of these transactions.

Table 4 shows that the reliability coefficient is $91 \%$. This indicates a high stability of the analysis. Based on the results of the analysis, the list of educational objectives was determined. The researcher determined the relative weights of the subjects, as well as established the relative weights of the cognitive levels (remembering - understanding) by determining the number of questions related to the subject matter and the number of questions related to each level of knowledge in the light of the list of objectives and cognitive concepts.

Ease, difficulty, and discrimination coefficient: Ease, difficulty, and discrimination coefficients for test vocabulary: the corrected ease coefficient was calculated from the effect of guesswork, difficulty, and the discrimination coefficient for each of the test items (according to the coefficient of corrected ease of estimation effect) through the results of the application of the test on the survey sample. The coefficient of ease and difficulty and the coefficient of discrimination were used to calculate the coefficient of ease and difficulty of the test as a whole, and were taken as: ease coefficient 1.3 , coefficient of difficulty 2.0 and coefficient of discrimination 0.26 .

\section{Evaluation stage}

To determine if the goals had been met, the pre and post-tests were made to measure the learners' engagement and achievements. Feedback from learners was considered. The next stage involved recording and monitoring data, and processing the data statistically, before the results were analyzed and discussed. Finally, the researcher was able to make recommendations and suggestions in light of the results. Data management and statistical analysis were conducted using a statistical package for the Social Sciences (SPSS) including the t-test, Arithmetic Averages, standard deviation and Eta squared.

\section{Results and Discussion}

After the completion of the study application and conducting the pre and post measurement of the two tools of the study, the data collected from the students of 
both the experimental and control groups were analyzed, and the results were found to be as follows.

There were no significant differences in the level of $a \leq 0.05$ between the mean scores in the instructional design subject (computer applications unit) of the experimental group, which used a flipped learning strategy, and the control group, which used a traditional method, on the pre and post-tests due to the program.

The t-test for the two independent samples was conducted to assure the equalization of two groups in the achievement pretest by having the same experience in terms of the computer applications unit. The results are shown below in Table 5 .

Table 5 shows that there are no statically significant differences between the mean scores of the experimental group (using a flipped learning strategy) and the control group (using a traditional method) on the pre-test achievement test. As $\mathrm{p} \leq 0.05$, it means it is accepted as a null hypothesis.

The t-test for the two independent samples was conducted to measure the study achievement of the two groups in terms of the computer applications unit during the post-test. The results are shown in Table 6 .

The results of the study analysis in Table 6 show the results $N=42, p<0.05$ from the experimental group of 22 students and a control group of 20 students. In terms of the students' achievements, the experimental group (taught using a flipped learning strategy) reported a means of $\overline{\mathrm{x}}=$ 23.045 in the posttest, with a standard deviation of $\sigma=1.617$, while the control group (taught using a traditional method) reported a mean score of $\overline{\mathrm{x}}=17.35$ posttest, with a standard deviation of $\sigma=1.785$.
After running a t-test on both the experimental and control group, it showed that the difference between the posttest $=5.69$, highlighting that there was an improvement in students' achievement based on their results in favor of experimental group. The fact the $\mathrm{P}$-value $=.022$ shows that there is a statistical significance at 40 $\mathrm{Df}$, and as $a \leq 0.05$, the results indicated that there were statistically significant differences in the achievement mean groups. Thus, the null hypothesis was accepted. In short, there were significant differences in the level of $a \leq 0.05$ between the mean scores in the instructional design subject (the computer applications unit) of the experimental group, which used a flipped learning strategy, and the control group, which used a traditional method, on the post-tests in favor of the experimental group. The findings showed that the experimental group did significantly better than the control group in terms of their achievements. The results also indicate that the use of flipped learning can improve students' achievements in the unit titled Computer Applications. The researcher attributed this to fact a flipped learning approach had been used, as it led to classroom discussion, and in turn, learners increased their understanding and thus reached a higher level of achievement. Also, the combination of pedagogy (learning theories) and instructional technology increased the opportunity for students to learn more deeply.

Using the flipped learning approach provides many benefits for the educational process, including more time spent by the teacher face-to-face with students, building a student-centered interactive classroom

Table 5

Equalization between the two groups (pre-test)

\begin{tabular}{lllllll}
\multicolumn{1}{c}{ Group } & $\mathrm{N}$ & Mean & Std.Deviation & T value & Df & Sig. (2-tailed) \\
\hline Experimental & 22 & 4.136 & 1.698 & 1.630 & 40 & .067 \\
Control & 20 & 13.35 & 1.424 & & \\
\hline \multicolumn{7}{c}{ Table 6 } \\
\multicolumn{7}{c}{ Post-test from the two groups } \\
\multicolumn{1}{c}{ Group } & $\mathrm{N}$ & Mean & Std. Deviation & T value & Df & Sig. (2-tailed) \\
\hline Experimental & 22 & 23.045 & 1.617 & & \\
Control & 20 & 17.35 & 1.785 & 10.806 & 40 & .022 \\
\hline
\end{tabular}


environment, taking into account individual differences, giving the teacher more time to help students, building stronger student-teacher relationships, allowing students to repeat the lesson more than once based on their individual differences, create an environment for cooperative learning in class and apply active learning easily. However, the traditional method did not increase students' achievement because they worked traditionally, which led to them lose focus, and therefore stop paying attention when learning about computer applications. In terms of academic achievement, the flipped learning and traditional learning approaches have been investigated in a number of studies. Regarding the post-test results, while some research suggests there is a significant difference in favor of flipped learning (Aljeser, 2017;; Sickle, 2016; Sun \& Wu, 2016; Webb \& Doman, 2016; Salimi \& Yousefzadeh, 2015; Gross,2014; Zhonggen \& Wang, 2016), others say that there is no significant difference between the flipped and traditional approach (Bishop, 2013; Brooks, 2014; Cashin, 2016; Clark, 2013; Crowford, 2017; Dixon, 2017; Faretta, 2016; Fraga \& Harmon, 2017; Howell, 2013; Johnson, 2012; Montgomery, 2015; Overmyer, 2014; Saunders, 2014; Sharpe, 2016; Smith, 2015; Winter, 2013; Johnson\&Renner, 2012).

There were no significant differences at the level of $a \leq 0.05$ between the mean scores of the first experimental group (taught using a flipped learning approach) and the control group (taught using a traditional method) in the pre and post-tests on engagement due to the program.

The t-test for the two independent samples was conducted to assure the equalization of the two groups in the pre-test re- garding engagement. Table 7 shows the results of the pre-test.

Table 7 shows that there are no statically significant differences between the mean scores of the experimental group (taught using a flipped learning strategy) and the control group (taught using a traditional method) on the pre-measurement in terms of engagement. As $p \leq 0.05$, it means it is accepted as a null hypothesis.

The t-test for the two independent samples was conducted on a scale to measure the engagement in learning of the two groups in the post-test. Table 8 shows the results of the post-measurement.

The results of the study analysis in Table 8 show the results $N=42, p<0.05$ for the experimental group of 22 students and control group of 20 students. In terms of the students' engagement measurement, the experimental group (taught using a flipped learning strategy) reported a means of $\bar{X}=92.45$ in the posttest, with a standard deviation of $\sigma=2.132$, while the control group (taught using a traditional method) reported a mean score of $\bar{X}=40.95$ posttest, with a standard deviation of $\sigma=$ 10.525. After running a t-test of experimental and control groups, it was shown that the difference between the posttest $=$ 51.50, highlighting that there was an improvement in students' engagement in learning in favor of experimental group based on the results. P-value $=.000$, which here is a statistical significance at $\mathrm{df}(40)$ and as $a \leq 0.05$, the results indicated that there were statistically significant differences in their engagement in learning mean groups. Thus, the null hypothesis was accepted. In short, there were significant differences in the level of $a \leq 0.05$

Table 7

Equalization between the two groups (pre-measurement of engagement)

\begin{tabular}{lcccccc}
\hline \multicolumn{1}{c}{ Group } & $\mathrm{N}$ & Mean & Std. Deviation & T value & Df & Sig. (2-tailed) \\
\hline Experimental & 22 & 9.454 & 4.992 & 1.597 & 40 & .442 \\
Control & 20 & 27.15 & 4.356 & \multicolumn{5}{c}{ Table 8 } \\
\hline \multicolumn{5}{c}{ Post-measurement of learning engagement } \\
\hline \multicolumn{1}{c}{ Group } & $\mathrm{N}$ & Mean & Std. Deviation & T value & Df & Sig. (2-tailed) \\
\hline Experimental & 22 & \multicolumn{2}{c}{2.132} & 21.49 & 40 & .000 \\
Control & 20 & $\begin{array}{c}92.454 \\
40.95\end{array}$ & 10.525 & & & \\
\hline
\end{tabular}


between the mean scores in the instructional design subject (the computer applications unit) of the experimental group, which used a flipped learning strategy, and their control group, which used a traditional method, on the post-tests in favor of the experimental group. The findings showed that the experimental group did significantly better than the control group in terms of their engagement while learning. The results indicate that the use of flipped learning can influence students' learning engagement measurement. The researcher attributed this to the impact that flipped learning has on sparking classroom discussion, which in turn lead to learners increasing their engagement. The results of the study analysis show that there is a strong, positive correlation between the use of flipped learning and students' engagement.

This finding is in line with those reported in prior literature, including Horn (2013), Kwon and Woo (2018), and Foldnes (2016). Roehl, Reddy and Shannon (2013) also stated that student taught in a flipped classroom become aware of their own learning process, as well as develop better communication and connection with others than students taught in a traditional setting. Another study that supports the results of this study is one conducted by Cronhjort, Filipsson, and Weurlander (2017), which revealed that the flipped classroom technique improved student's engagement and learning when compared to the traditional method. The aforementioned studies revealed that the flipped classroom approach led to a higher engagement of students compared to the traditional mode. Hence, the flipped classroom model could be regarded as invaluable for enhancing social connectedness and increasing the participation of students in their learning activities. In summary, the flipped classroom approach may develop students' confidence in developing their abilities and efforts when handling challenges.

Regarding the field of student engagement, the results and findings of this research study indicated that students were more involved and more engaged in the group that was taught using the flipped model than those who were taught by traditional delivery methods, which is consistent with the findings of other studies (Jamaludin \& Osman,2014); (Fulton, 2012); (Kahu, 2013); and (Dixon, 2010. This was also evident when the lecturer directed students to the activities in class, as they listened more carefully, paid attention, tried to do well and participated in the class activities. The researcher calculated the measures of association of this study. Table 9 shows the values of these transactions.

Table 9

\begin{tabular}{lcc}
\multicolumn{3}{c}{ Measures of Association } \\
\hline Test & Eta & Eta Squared \\
\hline Post-test* $^{*}$ group & & \\
& .966 & .914 \\
\hline
\end{tabular}

Table 9 shows the Eta squared for the total grades of the posttest for the subject of instructional design for the study sample (.914), which is equal to $91.4 \%$ from the grade changes of the posttests for both study groups, in favor of the experimental group that was taught using a flipped learning method.

\section{Conclusion}

The study aimed to establish the effectiveness of using a flipped learning approach in when teaching computer applications on students' engagement and achievement. The results showed that students were more engaged and more involved in the flipped model of instruction, and increased their achievement when compared to the traditional delivery approach. This was because students in the flipped classroom experienced quality instruction that was student-centered and student-focused. The flipped classroom also allowed for improved use of class time, and utilized various instructional strategies, including hands-on activities and project-based learning structures. While research into the effectiveness of the flipped model of instruction is limited, this research study has provided additional, valuable information regarding the model's impact on student engagement and achievement. Even though the flipped model of instruction is a relatively new instructional approach, it certainly has the 
potential to be deemed effective in terms of improving student engagement and achievement in the undergraduate classroom. Thus, it is concluded that the flipped learning strategy is an effective tool for teaching and learning the use of computer applications, as well as for increasing students' engagement, as the result was positive academic outcomes in education at university.

\section{Recommendations}

1. It is important to design pre-class learning activities and in-class learning activities according to the subject.

2. The use of the flipped learning strategy for teaching the instructional design course has a positive impact on students' level of engagement and achievement.

3. Educational materials should be provided in an electronic format to facilitate the application of the flipped learning strategy without the burden of producing electronic content.

\section{Suggestions}

1. More studies are needed to investigate the effectiveness of flipped learning on learning in other subjects.

2. A similar study to the current study should be conducted across different subjects.

3. A similar study should be conducted measuring the higher levels of Bloom's cognitive classification, analysis, synthesis and evaluation.

\section{References}

Ahlfeldt, S., Mehta, S., \& Sellnow, T. (2005). Measurement and analysis of student engagement in university classes where varying levels of PBL methods of instruction are in use. Higher Education Research and Development, 24(1), 5-20.

AlJaser, A. M. (2017). Effectiveness of using flipped classroom strategy in academic achievement and self-efficacy among education students of princess Nourah bint Abdulrahman University. English Language Teaching, 10(4), 6777.

Arnold-Gaza, S. (2014). The flipped classroom: A survey of the research. Communications In Information Literacy, 8(1), 8-22.

Bergman, J., \& Sams, A. (2012). Flip your classroom: Reach every student in every class every day. Washington: ISTE.

Berthelsen, D., Brownlee, J., \&Lewis, G. B. (2002). Caregivers' epistemological beliefs in toddler programs. Early Child Development and Care 172, 503 - 516.

Bishop, J. L. (2013). A controlled study of the flipped classroom with numerical methods for engineers. Unpublished doctoral dissertation. Utah State University.

Brame, C. J. (2013). Flipping the classroom. [Available online at: https://cft.vanderbilt.edu/wpcontent /uploads/sites/59/Flipping-theclassroom.pdf], Retrieved on June 29, 2018.

Brooks, A. (2014). Information literacy and the flipped classroom: Examining the impact of a one-shot flipped class on student learning and perceptions. Communications in Information Literacy, $8(2), 4$.

Cashin, M. (2016). The effect of flipped classrooms on elementary students' reading scores. Unpublished doctoral dissertation. Northcentral University.

Clark, K. R. (2013). Examining the effects of the flipped model of instruction on student engagement and performance in the secondary mathematics classroom: An action research study. Unpublished doctoral dissertation. Capella University.

Cormier, C., \& Voisard, B. (2018). Flipped classroom in organic chemistry has significant effect on students grades. Frontiers in ICT, 4(30), 1-15. doi: 10.3389/fict.2017.00030.

Crawford, T. H. (2017). Flipped learning influence on active learning and as- 
sessments in the postsecondary hospitality classroom: An action research study. Unpublished doctoral dissertation. Capella University.

Cronhjort, M. B., Filipsson, L.., \& Weurlander, M. (2017). Improved engagement and learning in flippedclassroom calculus. Teaching Mathematics and its Application, 37, 113-121. doi:10.1093/teamat/hrx007

Davies, R. S., Dean, D. L., \& Ball, N. (2013). Flipping the classroom and instructional technology integration in a college-level information systems spreadsheet course. Education Technology Research Development, 61, 563- 580. doi: 10.1007/s11423-013-9305-6

Dixon, K. L. (2017). The effect of the flipped classroom on urban high school students' motivation and academic achievement in a high school science. Unpublished doctoral dissertation. Liberty University, Lynchburg, VA.

Dixon, M. D. (2010). Creating effective student engagement in online courses: What do students find engaging? Journal of the Scholarship of Teaching and Learning, 10(2), 1-13.

Dixson, M. D.(2015). Measuring student engagement in the online course: The online student engagement scale (OSE). Online Learning, 19(4), 1-15.

Elian, S. A., \& Hamaidi, D.A.( 2018).The Effect of Using Flipped Classroom Strategy on the Academic Achievement of Fourth Grade Students in Jordan. International Journal of Emerging Technologies in Learning,13(2),110-125.

Emeka, U. J. and Nyeche, O. S. (2016). Impact of internet usage on the academic performance of undergraduate's students: A case study of the university of Abuja, Nigeria. International Journal of Scientific and Engineering Research, 7(10), 1018- 1029.

Estes. M., Ingram, R., \& Liu, J. (2014). A review of flipped classroom research, practice, and technologies. International HETL Review, 4(7).
Faretta, R. S. (2016). A causal-comparative inquiry into the significance of implementing a flipped classroom strategy in nursing education. Unpublished doctoral dissertation. Liberty University.

Foldnes, N. (2016). The flipped classroom and cooperative learning: Evidence from a randomised experiment. Active Learning in Higher Education,17(1), 114.

Fraga, L. M., \& Harmon, J. (2014). The flipped classroom model of learning in higher education: An investigation of preservice teachers' perspectives and achievement. Journal of Digital Learning in Teacher Education, 31(1), 18-27.

Fulton, K. P. (2012). 10 Reasons to Flip. New Styles of Instruction, 94(2), 20-24.

Fulton, K. P. (2012). Upside down and inside out: Flip your classroom to improve student learning. Learning $\mathcal{E}$ Leading with Technology, 39(8), 12-17

Geduld, B. (2016). Exploring differences between self-regulated learning strategies of high and low achievers in open distance learning. Africa Education Review, 13(1), 164-181.

Gross, A. (2014). The flipped classroom: Shakespeare in the English classroom. Ann Arbor, United States.

Horn, M. (2013). The Transformational Potential of Flipped Classrooms: Different strokes for different folks. Education Next,13(3), 78-79.

Howell, D. (2013). Effects of an Inverted Instructional Delivery Model on Achievement of Ninth-Grade Physical Science Honors Students. Unpublished doctoral dissertation. Gardner-Webb University

Huang, H. M. Rauch, U., and Liaw, S. S. (2010). Investigating learners 'attitudes toward virtual reality learning environments: Based on a constructivist approach. Computers and Education. 55(3)، 1171-1182. doi: 10.1016/j.compedu.2010.05.014

Hullman, J., Adar, E., and Shah, P. (2011). Benefitting infovis with visual difficul- 
ties. IEEE Transactions on Visualization and Computer Graphics, 17(12), 22132222. doi:10.1109/TVCG.2011.175

Jain, N., \& Singh, N. (2017). Effects of infographic designing on image processing ability and achievement motivation of $d y$ scalculia students, 8(2), 45-53.

Jamaludin, R., \& Osman, Z. M. (2014). The use of a flipped classroom to enhance engagement and promote active learning. Journal of Education and Practice,5(2) 124-131.

Jamaludin, R., \& Osman, S.Z.M.(2014).The Use of a Flipped Classroom to Enhance Engagement and Promote Active Learning. Journal of Education and Practice, 5(2),124-131.

Jdaitawi, M. (2019). The Effect of Flipped Classroom Strategy on Students Learning Outcomes. International Journal of Instruction,12(3),665-680.

Johnson, L., \&Renner, J. (2012). Effect of the flipped classroom model on a secondary computer applications course: Student and teacher perceptions, questions and student achievement. Unpublished doctoral dissertation. University of Louisville. Louisville, Kentucky.

Kahu, E. R. (2013). Framing student engagement in higher education. Studies in Higher Education, 38(5), 758- 773. doi: 10.1080/03075079.2011.598505

Karagöl, I., \& Esen, E. (2019).The effect of flipped learning approach on academic achievement: a meta-analysis study. H. U. Journal of Education, 34(3): 708727. doi: 10.16986/huje.2018046755.

Kettlewell, K., Southcott, C., Stevens, E., \& McCrone, T. (2012). Engaging the disengaged (NFER) Research Programme: From Education to Employment. Slough: NFER.

Kong, S. (2014). Developing information literacy and critical thinking skills through domain knowledge learning in digital classrooms: An experience of practicing flipped classroom strategy. Computers \& Education, 78, 160-173.
Kong, S. (2015). An experience of a threeyear study on the development of critical thinking skills in flipped secondary classrooms with pedagogical and technological support. Computers $\mathcal{E}$ Education, 89, 16-31. https://doi.org/10.1016/j.compedu.2 015.08.017.

Kwon, J.E., \& Woo, H. R. (2018). The Impact of flipped learning on cooperative and competitive mindsets. The Molecular Diversity Preservation International organization,10(79), 1-15.

Lage, M. J., Platt, G. J., \& Treglia, M. (2000). Inverting the classroom: A gateway to creating an inclusive learning environment. The Journal of Economic Education, 31(1), 30-43.

Lei, J. and Zhao, Y. (2007). Technology uses and student achievement: A longitudinal study. Science Direct, Computers and Education, 49(2), 284-296.

Leicht, R. M., Zappe, S. E., Messner, J. I., \& Litzinger, T. (2012) Employing the classroom flip to move "lecture" out of the classroom. Journal of Applications and Practices in Engineering Education, 3(1), 19-31

McLaughlin, J., Griffin, L., Esserman, D., Davidson, C., Glatt, D., Roth, M., \& Mumper, R. (2013). Pharmacy student engagement, performance, and perception in a flipped satellite classroom. American Journal of Pharmaceutical Education, 77(9), 1-8. doi: 10.5688/ajpe779196

Montgomery, J. (2015). The effects of flipped learning on middle school students' achievement with common core mathematics. Unpublished master thesis. California State University, San Marcos.

Ok, S., Erdogan, T., Yildirim, O., \& Cigdem, H. (2017). Effects of course delivery mode on students' self-regulation skills. International Conference on Education in Mathematics, Science \& Technology (ICEMST), May 19-22, Bodrum, Turkey.

Overmyer, G. R. (2014). The flipped classroom model for college algebra: Effects on student achievement. Un- 
published doctoral dissertation. Colorado State University.

Ozben, S. (2013). Social skills, life satisfaction, and loneliness in Turkish university students. Social behavior and Personality: An International Journal, 41, 203-214.

DOI: https://doi.org/10.2224/sbp.2013.41. 2.203

Reeve, J. (2013). How students create motivationally supportive learning environments for themselves: The concept of agentic engagement. Journal of Educational Psychology, 105(3), 579-595. doi: $10.1037 / \mathrm{a} 0032690$

Reiser, R. A., and Dempsey, J. V. (2007). Trends and Issues in Instructional Design and Technology. Upper Saddle River, N.J.: Person Education, Inc.

Roehl, A., Reddy, S. L., \& Shannon, G. J. (2013). The Flipped Classroom: An Opportunity To Engage Millennial Students Through Active Learning Strategies. JFCS,105(2), 1-7.

Sahin, S., Turan,. E. (2009). The effects and uses of educational technology in learning and teaching. Kastamonu Eğitim Dergisi,17 (1),321-330.

Salimi, A., \& Yousefzadeh, M. (2015). The effect of flipped learning (revised learning) on Iranian students' learning outcomes. Advances in Language and Literary Studies, 6(5), 209-213.

Sankoff, P. (2014). Taking the instructions of law outside of the lecture hall: How the Flipped classroom can make learning more productive and enjoyable (for professors and students). Alberta Law Review, 51(4), 891-906

Saunders, J. M. (2014). The flipped classroom: its effect on student academic achievement and critical thinking skills in high school mathematics. Unpublished doctoral thesis. Liberty University, Virginia.

Sergis, S., Sampson, D., \& Pelliccine, L. (2018). Investigating the impact of flipped classroom on students learning experience: A Self-Determination theory approach. Computer in Human Behavior, 78, 368-378.

Sharpe, E. H. (2016). An investigation of the flipped classroom in algebra two with trigonometry classes. Unpublished doctoral thesis. Regent University, London.

Sharpe, E. H. (2016). An investigation of the flipped classroom in algebra two with trigonometry classes. Unpublished doctoral thesis. Regent University, London.

Sickle, V. J. (2016). Discrepancies between student perception and achievement of learning outcomes in a flipped classroom. Journal of the Scholarship of Teaching and Learning, 16(2), 29-38.

Smith, J. P. (2015). The efficacy of a flipped learning classroom. Unpublished doctoral dissertation. McKendree University.

Strayer, J. (2007). The effects of the Classroom Flip on the Learning environment: a comparison of learning activity in a traditional classroom and a flip classroom that used an intelligent tutoring system. (Doctoral Dissertation), The Ohio state University.

Sun, J. C. Y., \& Wu, Y. T. (2016). Analysis of learning achievement and teacherstudent interactions in flipped and conventional classrooms. The International Review of Research in Open and Distributed Learning, 17(1), 79-99

Tarazi, N. (2016). The influence of the inverted classroom on student achievement and motivation for learning in secondary mathematics in the United Arab Emirates: A quasi-experimental study. Unpublished doctoral dissertation. Northcentral University.

Tucker, B. (2012). The flipped classroom: Online instruction at home frees class time for learning. Education Next, 12(1), 82-83.

Turki, F., Jdaitawi, M., \& Sheta, H. (2018). Fostering positive adjustment behavior: Social connectedness, achievement motivation and emotional-social learning among male and female university 
students. Active Learning in Higher Education, 19(2), 145- 158.

Warter-Perez, N., \& Dong, J. (2012). Flipping the Classroom: How to embed inquiry and design projects into a digital engineering lecture. Paper Presented at the American Society for Engineering Education, PSN Section Cal Poly, San Luis Obispo.

Webb, M., \& Doman, E. (2016). Does the flipped classroom lead to increased gains on learning outcomes in ESL/EFL contexts?. CATESOL Journal, 28(1), 39-67.

Wilson, S. G. (2013). The flipped class: A method to address the challenges of an undergraduate statistics course. Teaching of Psychology, 40(3), 193-199.

Winter, J. B. (2013). The effect of the flipped classroom model on achievement in an introductory college physics course. Unpublished doctoral dissertation. Mississippi State University.

Yuan, J. C., \& Wu, Y.T. (2016). Analysis of learning achievement and teacherstudent interactions in flipped and conventional classrooms. International Review of Research in Open and Distributed Learning, 17(1), 1-22.

Zhonggen, Y., \& Wang, G. (2016). Academic achievements and satisfaction of the clicker-aided flipped business English writing class. Journal of Educational Technology \& Society, 19(2), 298.

Zhou, G. \& Jiang, X. (2014). Theoretical Research and Instructional Design of the Flipped Classroom. Applied Mechanics and Materials, 543-547, 4312-4315.

Zorofi, M., Gargari, A., Geshlagi, M., \& Tahvildar, Z. (2011). The impact of media usage on students social skills. Research Journal of Applied Science, Engineering and Technology, 3(8), 731-736. 